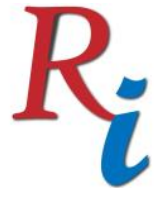

Asia Proceedings of Social Sciences

(APSS)

www.readersinsight.net/APSS

\title{
Effect of Corporate Governance Practices on the Earnings Management Practices: A Case of Pakistani Banking Sector
}

\section{Imran Yousaf*}

Air University School of Management, Air University, Islamabad, Pakistan

*Corrosponding author's Email: imranyousaf_12@pide.edu.pk 


\section{Research High Iight s}

Banks are highly focusing on real Corporate Governance practices to provide accurate and unbiased information in their annual financial reports but still managers are encouraged to do earnings managementr to beat expectations. Further, concentrated ownership in banks, give more benefit to majority shareholder as compare to minority shareholders which ultimately resulting in exploitation of the of minority shareholder's intersts, causing principal-principal(P-P) conflict. This study examines the effect of Corporate Governance practices and P-P conflicts on practices of Earning Management in banking Sector. This study uses regression analysis for estimation. The findings reveals that there is a inverse relationship between percentage of independent directors in Board and earning mangement Practices . Moreover ownership concentration is positively associated with the Earning Management Practices. This study has implications for management of the banks, regulatory bodies and for investors.

\section{Research High Iights}

Corporate Governance define as the rules and regulations through which all shareholders protect themselves from the exploitationof the insiders (La Porta et al., 2000). (Love, 2010) suggested that the minoity shareholders rights can be protacted after introducing Corporate Governeance mechanism in the firms. Siregar and Utama (2008) claims that the structure of corporate ownership plays a dynamic role in reducing the earning management activitiesand agency cost through real monitoring system. Yousaf and Hasan(2016) find that majority of the firms are based on family ownership(highly concentrated). Javid and Iqbal (2008) also find that few big shareholders has high percentage of ownership and control (Highly concentrated) in Pakistan and this factor ultimately effects the Governance Sysytem in Pakistan. These concentrated ownership based firms can be easily involved in earning management practices.

\section{Research Objectives}

This study examines the effect of Corporate Governance practices and P-P conflicts on practices of Earning Management in banking Sector. 


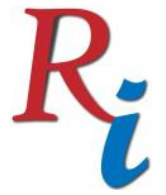

Asia Proceedings of Social Sciences

(APSS)

www.readersinsight.net/APSS

\section{Methodology}

This study uses regression analysis for estimation.

\section{Findings}

The findings reveals that there is a inverse relationship between percentage of independent directors in Board and earning mangement Practices . Moreover ownership concentration is positively associated with the Earning Management Practices

\section{References}

Javid, A. Y., \& Iqbal, R. (2008). Ownership concentration, corporate governance and firm performance: Evidence from Pakistan. The Pakistan Development Review, 643-659.

La Porta, R., Lopez-de-Silanes, F., Shleifer, A., \& Vishny, R. (2000). Investor protection and CGOV. Journal of financial economics, 58(1), 3-27.

Love, I. (2010). Corporate governance and performance around the world: What we know and what we don't. The World Bank Research Observer, 26(1), 42-70.

Siregar, S. V., \& Utama, S. (2008). Type of EM and the effect of ownership structure, firm size, and corporate-governance practices: Evidence from Indonesia. The international journal of accounting, 43(1), 1-27.

Yousaf, I., \& Hasan, A. (2016). Effect of family control on corporate financing decisions: A case of Pakistan (No. 2016: 138). Pakistan Institute of Development Economics. 